\title{
ANALISIS RISIKO TEKNOLOGI INFORMASI DI ORGANISASI XYZ CABANG SALATIGA MENGGUNAKAN ISO 31000
}

\author{
Sermon Paskah Zagoto', Melkior N.N. Sitokdana² \\ ${ }^{1,2}$ Sistem Informasi S1 Universitas Kristen Satya Wacana \\ 682017089@student.uksw.edu
}

\begin{abstract}
ABSTRAK
Organisasi XYZ Cabang Salatiga merupakan organisasi yang bergerak di bidang jasa pengiriman barang. Organisasi tersebut telah menggunakan teknologi informasi untuk menunjang aktivitas bisnis. TIKI KU merupakan aplikasi yang digunakan untuk mendata setiap pengiriman barang yang dilakukan oleh konsumen mulai dari data pengirim barang, data barang, dan data penerima barang. Namun tidak dapat dipungkiri, setiap risiko yang terjadi dapat mengganggu kinerja aplikasi TIKI KU. Oleh karena itu diperlukan analisis risiko terhadap teknologi informasi yang digunakan. Pada penelitian ini, peneliti mencoba mengimplementasikan kerangka kerja manajemen risiko ISO 31000 untuk melihat setiap kemungkinan risiko yang terdapat pada aplikasi TIKI KU. Hasil akhir dari penelitian ini diharapkan membantu organisasi dalam melihat serta mengetahui tindakan-tindakan apa saja yang harus dilakukan terhadap setiap kemungkinan risiko atau ancaman yang terjadi disekitar aplikasi TIKI KU berdasarkan level risikonya.
\end{abstract}

Keyword : analisis risiko, ISO 31000, risiko teknologi informasi, manajemen risiko.

\section{PENDAHULUAN}

Perkembangan Teknologi Informasi (TI) dari tahun ke tahun semakin berkembang. Perkembangan tersebut disebabkan oleh semakin meningkatnya kebutuhan organisasi. Setiap komponen yang ada didalam teknologi informasi harus mampu berjalan dengan baik sesuai dengan tugas dan fungsinya masing-masing sehingga dapat membantu organisasi menjalankan proses bisnis serta tercapainya visi misi organisasi.

Organisasi XYZ merupakan organisasi yang bergerak dibidang jasa pengiriman barang dan telah berdiri sejak tahun 1970. Hingga saat ini, Organisasi XYZ telah memiliki 65 kantor cabang yang tersebar di kota-kota besar di Indonesia. Sejak berdirinya Organisasi XYZ Cabang Salatiga, kantor cabang tersebut telah menggunakan Sistem Informasi/Teknologi Informasi (SI/TI) untuk menjalankan proses bisnis organisasi. Salah satu aplikasi yang digunakan yaitu aplikasi TIKI KU. TIKI KU merupakan aplikasi yang digunakan untuk mendata pengiriman barang yang dilakukan oleh konsumen seperti data pengirim barang, data barang, dan data penerima barang. Namun tidak dapat dipungkiri, kemungkinan ancaman dan risiko yang muncul disekitar aplikasi bisa saja terjadi. Risiko atau ancaman bisa saja terjadi pada aplikasi TIKI KU, maka dampak yang dihasilkan dapat mengganggu bahkan menghentikan aktivitas bisnis organisasi. Oleh karena itu pentingnya mengetahui risiko yang bisa berdampak terhadap kinerja aplikasi TIKI KU. Manfaat dari audit manajemen risiko yaitu memberikan gambaran risiko-risiko yang dapat muncul dari berbagai faktor yang berdampak buruk terhadap kinerja teknologi informasi organisasi kepada pihak stakeholder sehingga dapat mengambil keputusan dalam mengantisipasi risikorisiko yang bisa saja terjadi.
Salah satu tools berstandar internasional mengenai manajemen risiko yaitu ISO 31000. ISO 31000 merupakan pedoman standar, instruksi, dan tuntutan bagi sebuah organisasi untuk membangun sebuah pondasi dan kerangka kerja bagi suatu program manajemen risiko. Tujuan dari standarisasi ini adalah menyediakan prinsip-prinsip dan acuan dari program manajemen risiko kepada organisasi.

Tujuan penelitian ini adalah untuk mengetahui kemungkinan risiko atau ancaman yang terjadi di aplikasi TIKI KU dan dampak terjadinya risiko terhadap aktivitas bisnis serta memberikan rekomendasi terhadap setiap dampak yang timbul.

\section{TINJAUAN PUSTAKA}

\subsection{Penelitian Terdahulu}

Penelitian sebelumnya digunakan sebagai bahan referensi terhadap penelitian yang dilakukan saat ini. Terdapat beberapa penelitian tentang manajemen risiko atau analisis risiko menggunakan kerangka kerja ISO 31000, antara lain penelitian analisis risiko teknologi informasi F. Hutabarat dan A. Manuputty (2020) terhadap aplikasi VCare di PT. Visionet Data Internasional [1]. Penelitian tersebut dilakukan untuk melihat setiap kemungkinan risiko terhadap aplikasi VCare. Aplikasi tersebut digunakan untuk pendaftaran klien yang akan menggunakan layanan dari PT Visionet Data Internasional. Hasil akhir penelitian menghasilkan 20 kemungkinan risiko yang terbagi kedalam 4 kemungkinan risiko tergolong High, 8 kemungkinan risiko tergolong Medium, serta 8 kemungkinan risiko tergolong Low yang berpotensi menghambat kinerjasi aplikasi.

Selanjutnya penelitian analisis risiko teknologi informasi yang dilakukan oleh A. Rahmawati dan A. Wijaya (2019) di aplikasi IT Operation Support (iTop) pada PT. ABCD menghasilkan sebuah risiko teknologi informasi yang terdiri dari daftar dan 
faktor sehingga dapat menyebabkan terjadinya risiko yang mengancam kinerka aplikasi iTop [2]. Faktor-faktor tesebut antara lain, alam/lingkungan, kesalahan yang disengaja oleh manusia, dan dari sistem itu sendiri.

Penelitian analisis risiko teknologi informasi menggunakan kerangka kerja ISO 31000 juga dilakukan oleh S. Agustinus, A. Nugroho, dan A. Cahyano (2017) terhadap program HRMS. Program HRMS merupakan database pusat dari segala hal yang berkaitan dengan Human Resources Development dari PT. XYZ [3]. Penelitian tersebut bertujuan melakukan analisa risiko untuk mendapatkan dokumentasi terhadap berbagai macam kemungkinan risiko yang berada disekitar program HRMS. Dari penelitian yang dilakukan, ditemukan 26 kemungkinan risiko dan terbagi kedalam tiga level. Untuk level High terdapat 2 kemungkinan risiko, untuk level Medium terdapat 18 kemungkinan risiko, serta untuk level Low terdapat 6 kemungkinan risiko.

Penelitian terakhir yang digunakan sebagai bahan referensi terhadap penelitian yang dilakukan saat ini yaitu penelitian analisis risiko teknologi yang dilakukan oleh H. Driantami, Suprapto, dan A. Perdanakusuma (2018) di PT Matahari Department Store Cabang Malang Town Square menggunakan ISO 31000 [4]. Tujuan penelitian tersebut yaitu untuk mengetahui risiko IT terhadap sistem penjualan Alphapos yang dimana sistem itu digunakan untuk membantu seluruh kegiatan baik back office maupun front office. Yang mana untuk metodologi penelitian dibantu dengan menggunakan NIST 800-300 untuk menentukan peringkat risiko yang dihasilkan dari sistem penjualan Alphapos dan menentukan rekomendasi pengendalian cost-benefit analysis untuk setiap risiko yang termasuk kedalam daftar prioritas risiko.

\subsection{Landasan Teori}

Teknologi informasi merupakan sekumpulan alat yang saling terhubung yang akan membantu manusia dalam melakukan pekerjaannya. Teknologi informasi meliputi perangkat keras (hardware) dan perangkat lunak (software). Teknologi informasi membantu manusia mulai dari mengolah data menjadi informasi yang berguna bagi pengguna sehingga bisa menghasilkan keputusan yang baik berdasarkan data dan informasi yang tepat.

Manajemen risiko adalah suatu proses mengidentifikasi, mengukur risiko, serta membentuk strategi untuk mengelolanya menjadi sumber daya yang tersedia. Manajemen risiko bertujuan untuk mengelola risiko sehingga memperoleh hasil yang optimal [5].

Untuk mengetahui kemungkinan risiko, maka diperlukan proses identifikasi risiko pada aktivitas yang dilakukan oleh organisasi. Menurut D. Ramadhan, R. Febriansyah, dan R. Dewi (2020), identifikasi risiko adalah usaha untuk menemukan atau mengetahui risiko-risiko yang timbul yang ada di proses bisnis perusahaan [6]. Identifikasi risiko biasanya dilakukan di semua proses bisnis. Hal ini bertujuan untuk mengetahui semua risiko-risiko yang timbul yang mana berasal dari berbagai faktor.

Faktor-faktor yang dapat menimbulkan risiko bisa saja berasal dari alam, manusia, dan sistem/infrastruktur. Pertama faktor dari alam atau biasa disebut bencana alam. Faktor ini disebabkan oleh peristiwa alam seperti gempa bumi, tsunami, dan sebagainya. Kedua yaitu faktor dari manusia. Faktor ini disebabkan oleh adanya upaya merubah aplikasi/program secara sengaja. Hal ini dapat menimbulkan risiko seperti penyalahgunaan hak akses, cybercrime, pencirian data. Yang ketiga yaitu faktor dari sistem/infrastruktur. Faktor ini disebabkan oleh kegagalan saat sistem atau infrastruktur sedang berjalan.

Upaya untuk meminimalisir terjadinya risikorisiko yang tidak diinginkan yaitu dengan menerapkan manajemen risiko pada organisasi. Tujuan dari manajemen risiko adalah mengurangi risiko yang mungkin terjadi (ancaman), mengukur dampak dari potensi ancaman, dan menentukan kerugian yang diderita akibat hilangnya potensi bisnis [7].

Pada tanggal 13 November 2009 ISO 31000 standar internasional diterbitkan oleh The International Organization for Standarization. Standar tersebut dapat digunakan di segala jenis organisasi untuk menghadapi risiko yang berada pada aktivitas organisasi [4]. ISO 31000 adalah panduan penerapan risiko yang terdiri atas tiga elemen yaitu prinsip (principle), kerangka kerja (framework), dan proses (process). Salah satu hal yang membedakan ISO 31000 dengan standar manajemen risiko yang lain yaitu perspektif $I S O$ 31000 yang lebih luas dan lebih konseptual dibandingkan dengan yang lainnya. Hal ini ditandai dengan adanya kerangka kerja manajemen risiko yang merupakan implementasi prinsip manajemen mutu dan dikenal dengan "Plan-Do-Chek-Action" [4].

Dengan menggunakan kerangka kerja ISO 31000, maka kita dapat melakukan proses manajemen risiko di suatu organisasi. Kemudian membantu organisasi untuk meminimalisir kemungkinan risiko yang dapat ditimbulkan. Dengan begitu aktivitas bisnis organisasi dapat terus berjalan.

\section{METODE PENELITIAN}

\subsection{Metode Penelitian}

Metode penelitian yang akan digunakan penulis yaitu metode penelitian kualitatif. Menurut Zainal. A. Hasibuan, Ph.D (2007), penelitian kualitatif adalah penelitian yang bermaksud untuk memahami fenomena tentang apa yang akan dialami oleh subjek penelitian misalnya perilaku, persepsi, motivasi, tindakan, dan lain-lain, secara holistik dan 
deskripsi kata-kata dan bahasa, pada suatu konteks khusus yang alamiah dan dengan memanfaatkan berbagai metode alamiah [8]. Salah satu jenus penelitian kualitatif adalah berupa penelitian dengan metode atau pendakatan studi kasus (case study). Metode tersebut berfokus terhadap satu objek dengan menggunakan individu atau kelompok sebagai bahan studinya. Dengan metode ini, peneliti dengan mudah mengumpulkan data untuk menjawab permasalahan yang terjadi. Data yang digunakan dalam penelitian ini berupa data primer yang bersumber dari hasil wawancara bersama narasumber. Data yang didapatkan juga sudah diverifikasi dan divalidasi oleh narasumber. Sumber data diluar data primer tidak dapat digunakan karena tergolong kedalam data tersier [8].

\subsection{Metode Pengambilan Data}

Metode pengambilan data untuk penelitian ini yaitu dengan melakukan wawancara terhadap dua narasumber. Narasumber pertama yaitu Sales Counter yang bertugas mengisi data barang dari konsumen ke dalam aplikasi TIKI KU. Narasumber kedua yaitu Koordinatir TI yang bertugas menangani masalah pada saat aplikasi TIKI KU mengalami gangguan. Kedua narasumber tersebut sebagai sumber internal dari penelitian.

\subsection{Metode Analisis Data}

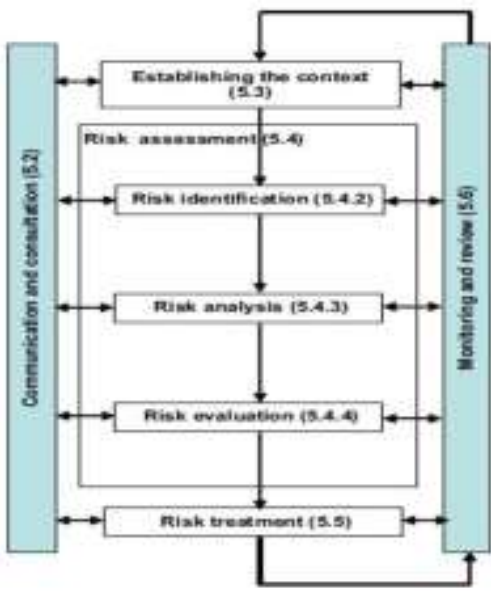

Gambar 1. Risk Management-Principles and Guidelines [9]

Penelitian ini menggunakan International Organization for Standarization (ISO 31000). Pada gambar diatas, terdapat 2 tahapan besar yaitu risk assessment (penilaian risiko) dan risk treatment (perlakuan risiko).

Tahap pertama yaitu tahap risk assessment (penilaian risiko). Pada tahap penilaian risiko, terdapat 3 proses yang dilakukan yaitu identifikasi risiko, analisis risiko, dan terakhir evaluasi risiko. Risk Identification (identifikasi risiko) adalah usaha untuk menemukan risiko-risiko yang timbul yang ada di proses bisnis perusahaan. Identifikasi risiko biasanya dilakukan di semua proses bisnis. Hal ini bertujuan untuk mengetahui semua risiko yang timbul yang mana berasal dari berbagai faktor [6]. Risk analysis (analisis risiko) yaitu proses melihat dampak/kerusakan yang ditimbulkan oleh risikorisiko sehingga menghambat jalannya proses bisnis. Risk evaluation (evaluas risiko) dilakukan untuk menentukan manajemen risiko dengan membandingkan tingkat risiko terhadap standar yang telah ditetapkan. Tujuannya yaitu untuk mengetahui tingkat prioritas tinggi hingga rendah dan mengetahui tingkat risiko mana yang harus ditindaklanjuti dan mana yang dipantau [10].

Tahap kedua yaitu tahap risk treatment (perlakuan risiko). Tahap ini dilakukan untuk menyeleksi kemungkinan-kemungkinan risiko, mengurangi bahkan menghilangkan dampak serta kemungkinan terjadinya risiko yang akan muncul [5].

\section{HASIL DAN PEMBAHASAN}

\subsection{Penilaian Risiko}

Tahap ini merupakan tahap penilaian risiko terhadap aplikasi TIKI KU yang terdiri dari identifikasi risiko, analisis risiko, dan evaluasi risiko.

\subsubsection{Identifikasi Risiko}

\section{a) Identifikasi Aset}

Pada tahap ini dilakukan identifikasi aset yang terdapat pada aplikasi TIKI KU mulai dari identifikasi aset data, perangkat lunak (software) dan perangkat keras (hardware). Proses identifikasi aset dilakukan dengan melakukan wawancara terhadap Sales Counter dan Koordinator TI.

Tabel 1. Identifikasi Aset

\begin{tabular}{|l|l|}
\hline \multicolumn{1}{|c|}{$\begin{array}{c}\text { Komponen Sistem } \\
\text { Informasi }\end{array}$} & \multicolumn{1}{|c|}{ Aset TIKI KU } \\
\hline Data & $\begin{array}{l}\text { Data User, Data } \\
\text { Pengirim, Data } \\
\text { Barang, Data Penerima }\end{array}$ \\
\hline Software & TIKI KU \\
\hline Hardware & $\begin{array}{l}\text { Personal Computer } \\
\text { (PC), Server Database }\end{array}$ \\
\hline
\end{tabular}

Sumber: Hasil Analisis Uji Coba Penelitian

Dari hasil analisis yang dilakukan untuk mengidentifikasi aset, didapatkan tiga komponen sistem informasi atau tiga aset. Pertama aset Data dengan isi data user, data pengirim barang, data barang, dan data penerima barang. Kedua aset perangkat lunak (software) yaitu TIKI KU. Aplikasi TIKI KU merupakan aplikasi yang digunakan untuk mendata setiap pengiriman barang yang dilakukan oleh konsumen. Aplikasi tersebut berjalan di atas Operating System (OS) Windows. Ketiga aset perangkat keras (hardware) yaitu Personal Computer $(P C)$ dan Server Database. Setiap Personal Computer $(P C)$ memiliki jumlah Random 
Acces Memory (RAM) sebesar 2GB dan Server Database juga memiliki jumlah RAM sebesar 8GB.

\section{b) Identifikasi Kemungkinan Risiko}

Setelah identifikasi aset terhadap aplikasi TIKI $\mathrm{KU}$, maka selanjutnya identifikasi kemungkinan risiko yang ada disekitar aplikasi. Identifikasi kemungkinan risiko terbagi kedalam 3 faktor.

Tabel 2. Identifikasi Kemungkinan Risiko

\begin{tabular}{|c|c|c|}
\hline Faktor & ID & Kemungkinan Risiko \\
\hline \multirow{5}{*}{ Alam } & R001 & Gempa Bumi \\
\hline & R002 & Tsunami \\
\hline & R003 & Banjir \\
\hline & R004 & Petir \\
\hline & R005 & Kebakaran \\
\hline \multirow{5}{*}{ Manusia } & R006 & Human Error \\
\hline & R007 & Penyalahgunaan Hak Ases \\
\hline & R008 & User Interface sulit dipahami \\
\hline & R009 & Hacking terhadap jaringan \\
\hline & R010 & Pencurian Data \\
\hline \multirow{10}{*}{ Sistem } & R011 & Listrik Padam \\
\hline & R012 & Server Down \\
\hline & R013 & $\begin{array}{l}\text { Koneksi internet tiba-tiba } \\
\text { putus }\end{array}$ \\
\hline & R014 & Data korup \\
\hline & R015 & Web Server bermasalah \\
\hline & R016 & Memori penuh \\
\hline & R017 & Overheat \\
\hline & R018 & Kerusakan hardware \\
\hline & R019 & Backup failure \\
\hline & R020 & $\begin{array}{l}\text { Tidak adanya sistem } \\
\text { Automatic Logout System }\end{array}$ \\
\hline
\end{tabular}

Sumber: Hasil Analisis Uji Coba Penelitian

Dari hasil identifikasi kemungkinan risiko, ditemukan 20 kemungkinan risiko atau ancaman yang berasal dari faktor alam, manusia, dan sistem.

c) Identifikasi Dampak Kemungkinan Risiko

Setelah mengidentifikasi kemungkinan risiko, selanjutnya menentukan dampak dari setiap kemungkinan risiko yang sudah diidentifikasi.

Tabel 3. Dampak Kemungkinan Risiko

\begin{tabular}{|c|l|l|}
\hline ID & $\begin{array}{c}\text { Kemungkinan } \\
\text { Risiko }\end{array}$ & \multicolumn{1}{|c|}{ Dampak } \\
\hline R001 & Gempa Bumi & $\begin{array}{l}\text { Kerusakan terhadap } \\
\text { infrastruktur dan } \\
\text { aktivitas bisnis berhenti. }\end{array}$ \\
\hline R002 & Tsunami & $\begin{array}{l}\text { Kerusakan terhadap } \\
\text { infrastruktur dan } \\
\text { aktivitas bisnis berhenti. }\end{array}$ \\
\hline R003 & Banjir & $\begin{array}{l}\text { Aktivitas pengiriman } \\
\text { barang tergganggu. }\end{array}$ \\
\hline R004 & Petir & $\begin{array}{l}\text { Aktivitas pengiriman } \\
\text { barang tergganggu. }\end{array}$ \\
\hline
\end{tabular}

\begin{tabular}{|c|c|c|}
\hline R005 & Kebakaran & $\begin{array}{lr}\text { Proses } & \text { layanan } \\
\text { pengiriman } & \text { barang } \\
\text { terganggu. } & \\
\end{array}$ \\
\hline R006 & Human Error & $\begin{array}{l}\text { Data yang diinputkan } \\
\text { tidak valid. }\end{array}$ \\
\hline R007 & $\begin{array}{l}\text { Penyalahgunaan } \\
\text { Hak Ases }\end{array}$ & $\begin{array}{lcc}\text { Hak akses } & \text { user } \\
\text { disalahgunakan. } & \\
\end{array}$ \\
\hline R008 & $\begin{array}{l}\text { User Interface } \\
\text { sulit dipahami }\end{array}$ & $\begin{array}{l}\text { User tidak memahami } \\
\text { penggunaa aplikasi TIKI } \\
\text { KU. }\end{array}$ \\
\hline R009 & $\begin{array}{l}\text { Hacking } \\
\text { terhadap } \\
\text { jaringan }\end{array}$ & $\begin{array}{l}\text { Aplikasi TIKI KU akan } \\
\text { mengalami gangguan. }\end{array}$ \\
\hline R010 & Pencurian Data & $\begin{array}{l}\text { Data klien dan data } \\
\text { informasi barang akan } \\
\text { disalahgunakan. }\end{array}$ \\
\hline R011 & Listrik Padam & $\begin{array}{lr}\text { Tidak } & \text { berpengaruh } \\
\text { karena Organisasi XYZ } \\
\text { Cabang } & \text { Salatiga } \\
\text { memiliki } & \text { cadangan } \\
\text { listrik. } & \\
\end{array}$ \\
\hline R012 & Server Down & $\begin{array}{l}\text { Aplikasi TIKI KU dan } \\
\begin{array}{l}\text { database } \\
\text { diakses. }\end{array} \\
\text { didak bisa } \\
\end{array}$ \\
\hline R013 & $\begin{array}{l}\text { Koneksi } \\
\text { internet tiba- } \\
\text { tiba putus }\end{array}$ & $\begin{array}{l}\text { Tidak dapat mengakses } \\
\text { aplikasi TIKI KU. }\end{array}$ \\
\hline R014 & Data korup & $\begin{array}{ll}\text { Data pengirim, } & \text { data } \\
\text { barang, dan } & \text { data } \\
\text { penerima rusak. } & \\
\end{array}$ \\
\hline R015 & $\begin{array}{l}\text { Web Server } \\
\text { bermasalah }\end{array}$ & $\begin{array}{l}\text { Tidak bisa akses ke } \\
\text { aplikasi TIKI KU. }\end{array}$ \\
\hline R016 & Memori penuh & $\begin{array}{l}\text { Data baru tidak dapat } \\
\text { masuk ke aplikasi TIKI } \\
\text { KU. }\end{array}$ \\
\hline R017 & Overheat & $\begin{array}{l}\text { Kerusakan pada } \\
\text { hardware karena suhu } \\
\text { meningkat dan akses ke } \\
\text { database terganggu. }\end{array}$ \\
\hline R018 & $\begin{array}{l}\text { Kerusakan } \\
\text { hardware }\end{array}$ & $\begin{array}{l}\text { Menghambat aktivitas } \\
\text { penginputan data barang } \\
\text { karena harus melakukan } \\
\text { konfigurasi ke hardware } \\
\text { baru. }\end{array}$ \\
\hline R019 & Backup failure & $\begin{array}{l}\text { Data pengirimbarang } \\
\text { dan data barang hilang. }\end{array}$ \\
\hline R020 & $\begin{array}{l}\text { Tidak adanya } \\
\text { sistem } \\
\text { Automatic } \\
\text { Logout System }\end{array}$ & $\begin{array}{l}\text { User meninggalkan } \\
\text { akses aplikasi TIKI KU } \\
\text { dalam keadaaan login } \\
\text { sehingga pengguna } \\
\text { selain user } \\
\text { menggunakan aplikasi } \\
\text { TIKI KU secara bebas } \\
\text { dan berpotensi terjadinya } \\
\text { pencurian data. }\end{array}$ \\
\hline
\end{tabular}

Sumber: Hasil Analisis Uji Coba Penelitian 


\subsubsection{Analisis Risiko}

Kemudian tahap selanjutnya yaitu analisis risiko. Pada tahap ini dilakukan penilaian terhadap kemungkinan risiko yang sudah diidentifikasi sebelumnya. Tabel 4 merupakan tabel kriteria likelohood. Dalam penelaian likelihood dibedakan kedalam 5 kriteria dengan kriteria laninya memiliki frekuensi kejadian yang berbeda.

Tabel 4. Kriteria Likelihood [2]

\begin{tabular}{|c|c|c|c|}
\hline \multicolumn{2}{|c|}{ Likelihood } & \multirow{2}{*}{ Deskripsi } & \multirow{2}{*}{$\begin{array}{c}\text { Frekuensi } \\
\text { Kejadian }\end{array}$} \\
\hline Nilai & Kriteria & & \\
\hline 1 & Rare & $\begin{array}{l}\text { Risiko hampir } \\
\text { tidak pernah } \\
\text { terjadi }\end{array}$ & $>2$ tahun \\
\hline 2 & Unlikely & $\begin{array}{l}\text { Risiko jarang } \\
\text { terjadi }\end{array}$ & 1-2 tahun \\
\hline 3 & Posibble & $\begin{array}{l}\text { Risiko kadang } \\
\text { terjadi }\end{array}$ & $\begin{array}{l}7-12 \\
\text { bulan }\end{array}$ \\
\hline 4 & Likely & $\begin{array}{l}\text { Risiko sering } \\
\text { terjadi }\end{array}$ & 4- 6 bulan \\
\hline 5 & Certain & $\begin{array}{l}\text { Risiko pasti } \\
\text { terjadi }\end{array}$ & 1-3 bulan \\
\hline
\end{tabular}

Tabel 5 merupakan tabel nilai impact atau dampak jika kemungkinan risiko terjadi di Organisasi XYZ Cabang Salatiga. Tabel penilaian dampak dibedakan kedalam 5 kriteria dan dikelompokkan mulai dari dampak yang paling tidak berpengaruh sampai dampak yang paling berpengaruh.

Tabel 5. Kriteria Impact [2]

\begin{tabular}{|c|c|c|}
\hline \multicolumn{2}{|c|}{ Impact } & \multirow{2}{*}{ Deskripsi } \\
\hline Nilai & Kriteria & \\
\hline 1 & Insignificant & $\begin{array}{l}\text { Tidak mengganggu } \\
\text { aktivitas bisnis } \\
\text { perusahaan }\end{array}$ \\
\hline 2 & Minor & $\begin{array}{l}\text { Aktivitas perusahaan } \\
\text { sedikit terhambat namun } \\
\text { aktivitas utama tidak } \\
\text { tergganggu }\end{array}$ \\
\hline 3 & Moderate & $\begin{array}{l}\text { Menghambat proses } \\
\text { bisnis sehingga sebagian } \\
\text { aktivitas terganggu }\end{array}$ \\
\hline 4 & Major & $\begin{array}{l}\text { Menghambat hampir } \\
\text { seluruh aktivitas } \\
\text { perusahaan }\end{array}$ \\
\hline 5 & Catastrophic & $\begin{array}{l}\text { Aktivitas perusahaan } \\
\text { terhenti karena aktivitas } \\
\text { bisnis mengalami } \\
\text { gangguan total }\end{array}$ \\
\hline
\end{tabular}

Selanjutnya dilakukan penilaian terhadap kemungkinan risiko berdasarkan tabel 4 dan tabel 5 .
Tabel 6. Penilaian Likelihood dan Impact

\begin{tabular}{|c|c|c|c|c|}
\hline Faktor & ID & $\begin{array}{c}\text { Kemungki } \\
\text { nan } \\
\text { Risiko }\end{array}$ & $\begin{array}{l}\text { Likeliho } \\
\text { od }\end{array}$ & $\underset{\text { ct }}{\text { Impa }}$ \\
\hline \multirow{5}{*}{ Alam } & R001 & $\begin{array}{l}\text { Gempa } \\
\text { Bumi }\end{array}$ & 3 & 5 \\
\hline & R002 & Tsunami & 1 & 5 \\
\hline & R003 & Banjir & 2 & 4 \\
\hline & R004 & Petir & 3 & 4 \\
\hline & R005 & Kebakaran & 1 & 5 \\
\hline \multirow{5}{*}{$\begin{array}{l}\text { Manu } \\
\text { sia }\end{array}$} & R006 & $\begin{array}{l}\text { Human } \\
\text { Error }\end{array}$ & 3 & 3 \\
\hline & R007 & $\begin{array}{l}\text { Penyalahg } \\
\text { unaan Hak } \\
\text { Ases }\end{array}$ & 2 & 3 \\
\hline & R008 & $\begin{array}{l}\text { User } \\
\text { Interface } \\
\text { sulit } \\
\text { dipahami }\end{array}$ & 4 & 4 \\
\hline & R009 & $\begin{array}{l}\text { Hacking } \\
\text { terhadap } \\
\text { jaringan }\end{array}$ & 1 & 4 \\
\hline & R010 & $\begin{array}{l}\text { Pencurian } \\
\text { Data }\end{array}$ & 1 & 4 \\
\hline \multirow{10}{*}{$\begin{array}{l}\text { Siste } \\
\mathrm{m}\end{array}$} & R011 & $\begin{array}{l}\text { Listrik } \\
\text { Padam } \\
\end{array}$ & 3 & 3 \\
\hline & R012 & $\begin{array}{l}\text { Server } \\
\text { Down }\end{array}$ & 4 & 4 \\
\hline & R013 & $\begin{array}{l}\text { Koneksi } \\
\text { internet } \\
\text { tiba-tiba } \\
\text { putus }\end{array}$ & 4 & 4 \\
\hline & R014 & Data korup & 1 & 3 \\
\hline & R015 & $\begin{array}{l}\text { Web } \\
\text { Server } \\
\text { bermasala } \\
\mathrm{h}\end{array}$ & 4 & 3 \\
\hline & R016 & $\begin{array}{l}\text { Memori } \\
\text { penuh }\end{array}$ & 2 & 2 \\
\hline & R017 & Overheat & 1 & 1 \\
\hline & R018 & $\begin{array}{l}\text { Kerusakan } \\
\text { hardware }\end{array}$ & 1 & 2 \\
\hline & R019 & $\begin{array}{l}\text { Backup } \\
\text { failure }\end{array}$ & 2 & 1 \\
\hline & R020 & $\begin{array}{l}\text { Tidak } \\
\text { adanya } \\
\text { sistem } \\
\text { Automatic } \\
\text { Logout } \\
\text { System } \\
\end{array}$ & 2 & 1 \\
\hline
\end{tabular}

Sumber: Hasil Analisis Uji Coba Penelitian 


\subsubsection{Evaluasi Risiko}

Tahap terakhir yaitu tahap evaluasi risiko. Tahap ini menggunakan acuan berupa matrix evaluasi risiko, dimana dilakukan pemetaan terhadap level risiko berdasarkan penilaian terhadap kemungkinan risiko dan ancaman di sekitar aplikasi TIKI KU.

Tabel 7. Matrix Evaluasi Risiko [1]

\begin{tabular}{|c|c|c|c|c|c|c|c|}
\hline \multirow{5}{*}{ 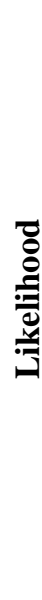 } & $\begin{array}{c}\text { Cer } \\
\text { tai } \\
\text { n }\end{array}$ & 5 & $\begin{array}{c}\text { Medi } \\
\text { um }\end{array}$ & $\begin{array}{c}\mathrm{Me} \\
\text { diu } \\
\mathrm{m}\end{array}$ & $\underset{\mathrm{h}}{\mathrm{Hig}}$ & $\begin{array}{c}\mathrm{Hig} \\
\mathrm{h}\end{array}$ & High \\
\hline & $\begin{array}{l}\text { Lik } \\
\text { ely }\end{array}$ & 4 & $\begin{array}{l}\text { Medi } \\
\text { um }\end{array}$ & $\begin{array}{c}\mathrm{Me} \\
\text { diu } \\
\mathrm{m}\end{array}$ & $\begin{array}{c}\text { Med } \\
\text { ium }\end{array}$ & $\begin{array}{c}\mathrm{Hig} \\
\mathrm{h}\end{array}$ & High \\
\hline & $\begin{array}{c}\text { Pos } \\
\text { sibl } \\
\text { e } \\
\end{array}$ & 3 & Low & $\begin{array}{c}\mathrm{Me} \\
\text { diu } \\
\mathrm{m}\end{array}$ & $\begin{array}{c}\text { Med } \\
\text { ium }\end{array}$ & $\begin{array}{c}\mathrm{Me} \\
\text { diu } \\
\mathrm{m}\end{array}$ & High \\
\hline & $\begin{array}{c}\text { Unl } \\
\text { ikel } \\
\mathbf{y}\end{array}$ & 2 & Low & $\begin{array}{l}\text { Lo } \\
w\end{array}$ & $\begin{array}{c}\text { Med } \\
\text { ium }\end{array}$ & $\begin{array}{c}\mathrm{Me} \\
\text { diu } \\
\mathrm{m}\end{array}$ & $\begin{array}{c}\text { Medi } \\
\text { um }\end{array}$ \\
\hline & $\begin{array}{c}\text { Im } \\
\text { pac } \\
\mathbf{t}\end{array}$ & 1 & Low & $\begin{array}{l}\text { Lo } \\
w\end{array}$ & Low & $\begin{array}{c}\mathrm{Me} \\
\text { diu } \\
\mathrm{m} \\
\end{array}$ & $\begin{array}{c}\text { Medi } \\
\text { um }\end{array}$ \\
\hline \multirow{2}{*}{\multicolumn{3}{|c|}{ Impact }} & 1 & 2 & 3 & 4 & 5 \\
\hline & & & $\begin{array}{c}\text { Insig } \\
\text { nifica } \\
\text { nt } \\
\end{array}$ & $\begin{array}{l}\text { Mi } \\
\text { nor }\end{array}$ & $\begin{array}{l}\text { Mo } \\
\text { der } \\
\text { ate } \\
\end{array}$ & $\begin{array}{c}\text { Ma } \\
\text { jor }\end{array}$ & $\begin{array}{c}\text { Catas } \\
\text { troph } \\
\text { ic } \\
\end{array}$ \\
\hline
\end{tabular}

Pada tabel matrix evaluasi risiko diatas terdapat tiga warna yaitu Merah, Kuning, dan Hijau. Warna Merah diartikan sebagai level risiko High, yang artinya kemungkinan risiko tersebut sering terjadi dan memiliki dampak besar terdapat aktivitas bisnis organisasi. Untuk warna Kuning diartikan sebagai level risiko Medium, yang artinya kemungkinan risiko tersebut jarang terjadi dan memiliki dampak sedikit terhadap aktivitas bisnis organisasi. Sedangkan untuk warna Hijau diartikan sebagai level risiko Low, yang artinya kemungkinan risiko tesebut hampir tidak pernah terjadi dan tidak memiliki dampak sama sekali terhadap aktivitas bisnis organisasi.

Tahap selanjutnya yaitu mengevaluasi risiko berdasarkan identitas kemungkinan risiko kedalam parameter sesuai dengan kriteria Likelihood dan kriteria Impact.

Tabel 8. Matrix Evaluasi Risiko Berdasarkan Likelihood dan Impact

\begin{tabular}{|c|c|c|c|c|c|c|}
\hline & $\begin{array}{l}\text { Cer } \\
\text { tain }\end{array}$ & 5 & R020 & & & \\
\hline ت & $\begin{array}{c}\text { Lik } \\
\text { ely }\end{array}$ & 4 & & R015 & $\begin{array}{l}\text { R008 } \\
\text { R012 } \\
\text { R013 }\end{array}$ & \\
\hline 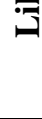 & $\begin{array}{c}\text { Pos } \\
\text { sibl } \\
\text { e }\end{array}$ & 3 & & $\begin{array}{l}\text { R006 } \\
\text { R011 }\end{array}$ & R004 & $\begin{array}{c}\mathrm{R} 00 \\
1\end{array}$ \\
\hline
\end{tabular}

\begin{tabular}{|c|c|c|c|c|c|}
\hline $\begin{array}{c}\text { Unl } \\
\text { ikel } \\
\mathbf{y}\end{array}$ & 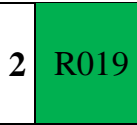 & $\begin{array}{l}\text { R0 } \\
16\end{array}$ & R007 & R003 & \\
\hline $\begin{array}{c}\text { Im } \\
\text { pac } \\
\mathbf{t}\end{array}$ & $\mathbf{1} \mathrm{R} 017$ & $\begin{array}{c}\text { R0 } \\
18\end{array}$ & R014 & $\begin{array}{l}\text { R009 } \\
\text { R010 }\end{array}$ & $\begin{array}{c}\text { R00 } \\
2 \\
\text { R00 } \\
5\end{array}$ \\
\hline \multirow[b]{2}{*}{ Impact } & 1 & 2 & 3 & 4 & 5 \\
\hline & $\begin{array}{c}\text { Insig } \\
\text { nific } \\
\text { ant }\end{array}$ & $\begin{array}{l}M \\
\text { in } \\
\text { or }\end{array}$ & $\begin{array}{l}\text { Mod } \\
\text { erate }\end{array}$ & $\begin{array}{c}\text { Maj } \\
\text { or }\end{array}$ & $\begin{array}{l}\text { Cat } \\
\text { astr } \\
\text { oph } \\
\text { ic }\end{array}$ \\
\hline
\end{tabular}

Sumber: Hasil Analisis Uji Coba Penelitian

Setelah kemungkinan risiko telah dimasukkan kedalam matrix evaluasi risiko, maka selanjutnya mengelompokkan 20 kemungkinan risiko berdasarkan tingkatan level mulai dari High, Medium, dan Low.

Tabel 9. Pengelompokkan Risiko Berdasarkan Tingkatan

\begin{tabular}{|c|c|c|c|c|}
\hline ID & $\begin{array}{c}\text { Kemungkinan } \\
\text { Risiko }\end{array}$ & $\begin{array}{l}\text { Likel } \\
\text { ihood }\end{array}$ & $\begin{array}{r}\text { Imp } \\
\text { act }\end{array}$ & $\begin{array}{l}\text { Risk } \\
\text { Level }\end{array}$ \\
\hline R001 & Gempa Bumi & 3 & 5 & High \\
\hline R008 & $\begin{array}{l}\text { User Interface } \\
\text { sulit dipahami }\end{array}$ & 4 & 4 & High \\
\hline R012 & Server down & 4 & 4 & High \\
\hline R013 & $\begin{array}{l}\text { Koneksi } \\
\text { internet tiba- } \\
\text { tiba terputus }\end{array}$ & 4 & 4 & High \\
\hline R002 & Tsunami & 1 & 5 & Medium \\
\hline R005 & Kebakaran & 1 & 5 & Medium \\
\hline R004 & Petir & 3 & 4 & Medium \\
\hline R003 & Banjir & 2 & 4 & Medium \\
\hline R009 & $\begin{array}{l}\text { Hacking } \\
\text { terhadap } \\
\text { jaringan }\end{array}$ & 1 & 4 & Medium \\
\hline R010 & Pencurian data & 1 & 4 & Medium \\
\hline R015 & $\begin{array}{l}\text { Web Server } \\
\text { bermasalah }\end{array}$ & 4 & 3 & Medium \\
\hline R006 & Human Error & 3 & 3 & Medium \\
\hline R007 & $\begin{array}{l}\text { Penyalahgunaa } \\
\mathrm{n} \text { hak akses }\end{array}$ & 2 & 3 & Medium \\
\hline R011 & Listrik Padam & 3 & 3 & Medium \\
\hline R020 & $\begin{array}{l}\text { Tidak adanya } \\
\text { Automatic } \\
\text { Logout System }\end{array}$ & 5 & 1 & Medium \\
\hline R014 & Data korup & 1 & 3 & Low \\
\hline R016 & Memori penuh & 2 & 2 & Low \\
\hline R018 & $\begin{array}{l}\text { Kerusakan } \\
\text { hardware }\end{array}$ & 1 & 2 & Low \\
\hline R019 & Backup failure & 2 & 1 & Low \\
\hline R017 & Overheat & 1 & 1 & Low \\
\hline
\end{tabular}

Sumber: Hasil Analisis Uji Coba Penelitian

Dari hasil proses evaluasi risiko, terlihat pada tabel 9 terdapat 20 kemungkinan risiko yang sudah dianalisa dan diurutkan berdasarkan level risikonya. 
Terdapat 4 kemungkinan risiko tergolong High mulai dari gempa bumi, user inteface sulit dipahami, server down, serta koneksi internet tiba-tiba terputus. 11 kemungkinan risiko tergolong Medium seperti tsunami, kebakaran, petir, banjir, hacking terhadap jaringan, pencurian data, web server bermasalah, human error, penyalahgunaan hak akses, listrik mati, dan tidak adanya automatic logout system. Dan terakhir 5 kemungkinan risiko tergolong Low mulai dari data korup, kerusakan hardware, backup failure, dan overheat.

\subsection{Perlakuan Risiko}

Setelah melalui tahap identifikasi risiko, maka tahap terakhir yaitu tahap perlakukan risiko. Pada tahap ini, diberikan usulan tindakan risiko untuk setiap kemungkinan risiko. Dengan adanya usulan tindakan risiko, diharapkan dapat mengurangi atau meminimaliris setiap kemungkinan-kemungkinan risiko yang terjadi disekitar aplikasi TIKI KU.

Tabel 10. Usulan Perlakuan Risiko

\begin{tabular}{|c|c|c|c|}
\hline ID & $\begin{array}{l}\text { Kemun } \\
\text { gkinan } \\
\text { Risiko }\end{array}$ & $\begin{array}{c}\text { Risk } \\
\text { Level }\end{array}$ & Tindakan Risiko \\
\hline $\begin{array}{l}\mathrm{R} 0 \\
01\end{array}$ & $\begin{array}{l}\text { Gempa } \\
\text { Bumi }\end{array}$ & High & $\begin{array}{l}\text { Menyediakan } \\
\text { cadangan server } \\
\text { ditempat yang aman }\end{array}$ \\
\hline $\begin{array}{l}\mathrm{R} 0 \\
08\end{array}$ & $\begin{array}{l}\text { User } \\
\text { Interfac } \\
e \quad \text { sulit } \\
\text { dipaha } \\
\text { mi }\end{array}$ & High & $\begin{array}{l}\text { Menyediakan buku } \\
\text { panduan tentang } \\
\text { penggunaan aplikasi } \\
\text { TIKI KU kepada } \\
\text { setiap karyawan. } \\
\text { Memberikan } \\
\text { pelatihan dan } \\
\text { petunjuk penggunaan } \\
\text { aplikasi TIKI KU } \\
\text { kepada } \text { user. }\end{array}$ \\
\hline $\begin{array}{l}\text { R0 } \\
12\end{array}$ & $\begin{array}{l}\text { Server } \\
\text { down }\end{array}$ & High & $\begin{array}{l}\text { Melakukan } \\
\text { pengecekan secara } \\
\text { berkala terhadap } \\
\text { dblog, temp dblog, } \\
\text { CPU usage, dan RAM } \\
\text { usage pada server }\end{array}$ \\
\hline $\begin{array}{l}\text { R0 } \\
13\end{array}$ & $\begin{array}{l}\text { Koneks } \\
\text { i } \\
\text { internet } \\
\text { tiba- } \\
\text { tiba } \\
\text { terputus }\end{array}$ & High & $\begin{array}{l}\text { Segera melaporkan ke } \\
\text { pihak Internet Service } \\
\text { Provider }(I S P)\end{array}$ \\
\hline $\begin{array}{l}\text { R0 } \\
02\end{array}$ & $\begin{array}{l}\text { Tsunam } \\
\text { i }\end{array}$ & Medium & $\begin{array}{l}\text { Menyediakan } \\
\text { cadangan server } \\
\text { dilokasi yang berbeda } \\
\text { dan memindahkan } \\
\text { aset kantor yaitu } \\
\text { hardware ke tempat } \\
\text { yang lebih tinggi }\end{array}$ \\
\hline $\begin{array}{l}\text { R0 } \\
05\end{array}$ & $\begin{array}{l}\text { Kebaka } \\
\text { ran }\end{array}$ & Medium & $\begin{array}{l}\text { Menyediakan alat } \\
\text { pemadam kebakaran } \\
\text { agar tidak terjadi }\end{array}$ \\
\hline
\end{tabular}

\begin{tabular}{|c|c|c|c|}
\hline & & & $\begin{array}{l}\text { kerusakan pada } \\
\text { hardware }\end{array}$ \\
\hline $\begin{array}{l}\text { R0 } \\
04\end{array}$ & Petir & Medium & $\begin{array}{l}\text { Memasang } \\
\text { penangkal petir di } \\
\text { gedung }\end{array}$ \\
\hline $\begin{array}{l}\text { R0 } \\
03\end{array}$ & Banjir & Medium & $\begin{array}{l}\text { Menyediakan } \\
\text { cadangan server } \\
\text { dilokasi yang berbeda } \\
\text { dan memindahkan } \\
\text { aset kantor yaitu } \\
\text { hardware ke tempat } \\
\text { yang lebih tinggi }\end{array}$ \\
\hline $\begin{array}{l}\text { R0 } \\
09\end{array}$ & $\begin{array}{l}\text { Hackin } \\
g \\
\text { terhada } \\
\mathrm{p} \\
\text { jaringan }\end{array}$ & Medium & $\begin{array}{l}\text { Menggunakan } \\
\text { jaringan private agar } \\
\text { sulit diretas }\end{array}$ \\
\hline $\begin{array}{l}\mathrm{R} 0 \\
10\end{array}$ & $\begin{array}{l}\text { Pencuri } \\
\text { an data }\end{array}$ & Medium & $\begin{array}{l}\text { Memasang alat } C C T V \\
\text { disetiap ruangan }\end{array}$ \\
\hline $\begin{array}{l}\text { R0 } \\
15\end{array}$ & $\begin{array}{l}\text { Web } \\
\text { Server } \\
\text { bermas } \\
\text { alah }\end{array}$ & Medium & $\begin{array}{l}\text { Memberitahu kepada } \\
\text { user bahwa akses ke } \\
\text { aplikasi TIKI KU } \\
\text { akan gagal. } \\
\text { Memperbaiki web } \\
\text { server agar kembali } \\
\text { normal. }\end{array}$ \\
\hline $\begin{array}{l}\text { R0 } \\
06\end{array}$ & $\begin{array}{l}\text { Human } \\
\text { Error }\end{array}$ & Medium & $\begin{array}{l}\text { Melakukan pelatihan } \\
\text { kepada } \\
\text { karyawan/calon } \\
\text { karyawan dalam } \\
\text { menggunakan } \\
\text { aplikasi TIKI KU }\end{array}$ \\
\hline $\begin{array}{l}\text { R0 } \\
07\end{array}$ & $\begin{array}{l}\text { Penyala } \\
\text { hgunaa } \\
\mathrm{n} \quad \text { hak } \\
\text { akses }\end{array}$ & Medium & $\begin{array}{l}\text { Memberi konfirmasi } \\
\text { login saat user login } \\
\text { ke aplikasi TIKI KU }\end{array}$ \\
\hline $\begin{array}{l}\text { R0 } \\
11\end{array}$ & $\begin{array}{l}\text { Listrik } \\
\text { Padam }\end{array}$ & Medium & $\begin{array}{l}\text { Menyediakan } \\
\text { generator set dan } \\
\text { UPS (Uninterruptible } \\
\text { Power Supply) } \\
\text { dengan daya yang } \\
\text { disesuaikan dengan } \\
\text { kondisi organisasi }\end{array}$ \\
\hline $\begin{array}{l}\text { R0 } \\
20\end{array}$ & $\begin{array}{l}\text { Tidak } \\
\text { adanya } \\
\text { Automa } \\
\text { tic } \\
\text { Logout } \\
\text { System }\end{array}$ & Medium & $\begin{array}{l}\text { Membuat sistem } \\
\text { automatic logout } \\
\text { system, agar ketika } \\
\text { user login ke aplikasi } \\
\text { TIKI KU dan lupa } \\
\text { untuk logout, maka } \\
\text { sistem otomatis akan } \\
\text { logout. Hal ini perlu } \\
\text { dilakukan untuk } \\
\text { menghindari orang- } \\
\text { orang yang tidak } \\
\text { memiliki hak akses } \\
\text { terhadap aplikasi } \\
\text { TIKI KU. }\end{array}$ \\
\hline $\begin{array}{l}\text { R0 } \\
14\end{array}$ & $\begin{array}{l}\text { Data } \\
\text { korup }\end{array}$ & Low & $\begin{array}{l}\text { Melakukan backup } \\
\text { data terhadap aplikasi } \\
\text { TIKI KU. }\end{array}$ \\
\hline
\end{tabular}




\begin{tabular}{|c|c|c|c|}
\hline & & & $\begin{array}{l}\text { Selalu } \\
\text { memperhatikan file } \\
\text { yang telah di } \\
\text { download/unduh dari } \\
\text { internet. Hal ini } \\
\text { diperlukan untuk } \\
\text { melihat apalah file } \\
\text { yang telah di undah } \\
\text { merupakan virus atau } \\
\text { bukan sehingga } \\
\text { menegah kehilangan } \\
\text { dan kerusakan data. }\end{array}$ \\
\hline $\begin{array}{l}\text { R0 } \\
16\end{array}$ & $\begin{array}{l}\text { Memori } \\
\text { penuh }\end{array}$ & Low & \begin{tabular}{lr}
\multicolumn{2}{l}{ Memperhatikan } \\
penggunaan memori \\
penyimpanan \\
database & secara \\
berkala agar jangan \\
sampai penuh
\end{tabular} \\
\hline $\begin{array}{c}\text { R0 } \\
18\end{array}$ & $\begin{array}{l}\text { Kerusa } \\
\text { kan } \\
\text { hardwa } \\
\text { re }\end{array}$ & Low & $\begin{array}{l}\text { Melakukan perawatan } \\
\text { dan memberikan } \\
\text { asuransi terhadap aset } \\
\text { hardware yang } \\
\text { dimiliki }\end{array}$ \\
\hline $\begin{array}{l}\text { R0 } \\
19\end{array}$ & $\begin{array}{l}\text { Backup } \\
\text { failure }\end{array}$ & Low & $\begin{array}{l}\text { Melakukan } \\
\text { pengecekan secara } \\
\text { berkalan. } \\
\text { Melakukan backup } \\
\text { data yang terdapat } \\
\text { pada aplikasi TIKI } \\
\text { KU. }\end{array}$ \\
\hline $\begin{array}{l}\text { R0 } \\
17\end{array}$ & $\begin{array}{l}\text { Overhe } \\
\text { at }\end{array}$ & Low & $\begin{array}{lr}\text { Menyediakan AC (air } \\
\text { conditioner) pada } \\
\text { ruangan agar suhu } \\
\text { tetap stabil }\end{array}$ \\
\hline
\end{tabular}

Sumber: Hasil Analisis Uji Coba Penelitian

\section{KESIMPULAN}

Berdasarkan dari peneltian yang sudah dilakukan, analisis risiko teknologi informasi aplikasi TIKI KU di Organisasi XYZ Cabang Salatiga dijalankan melalui dua tahapan besar. Tahap pertama yaitu tahap penilaian risiko meliputi identifikasi risiko, analisis risiko, dan evaluasi risiko. Dan tahap kedua yaitu tahap perlakuan risiko.

Dari hasil penelitian yang telah dilakukan, terdapat 4 kemungkinan risiko dengan level risiko High, 11 kemungkinan risiko dengan level risiko Medium, dan 5 kemungkinan risiko dengan level risiko Low. Level risiko High merupakan level risiko yang pasti terjadi dan memiliki dampak langsung terhadap aktivitas bisnis organisasi. Untuk itu perlu dilakukan tindakan risiko untuk meminimalisir hal tesebut. Solusi yang dilakukan yaitu dengan menyediakan server cadangan jika terjadi gempa bumi, menyediakan buku panduan penggunaan aplikasi TIKI KU kepada karyawan, melakukan pengecekan secara berkala terhadap server untuk menghindari server down, serta melaporkan kepada ISP jika koneksi internet tiba-tiba terputus.
Setelah dilakukan penelitian ini, diharapkan setiap kemungkinan-kemungkinan risiko yang terjadi di sekitar aplikasi TIKI KU dapat diminimalisir agar aktivitas Organisasi XYZ Cabang Salatiga dapat terus berjalan.

\section{DAFTAR PUSTAKA}

[1] F. M. Hutabarat and A. D. Manuputty, "Analisis Resiko Teknologi Informasi Aplikasi VCare PT Visionet Data Internasional Menggunakan ISO 31000," J. Bina Komput., vol. 2, no. 1, pp. 52-65, 2020, doi: 10.33557/binakomputer.v2i1.792.

[2] A. Rahmawati and A. F. Wijaya, "Analisis Risiko Teknologi Informasi Menggunakan ISO 31000 Pada Aplikasi ITOP," J. SITECH Sist. Inf. dan Teknol., vol. 2, no. 1, pp. 13-20, 2019, doi: 10.24176/sitech.v2i1.3122.

[3] S. Agustinus, A. Nugroho, and A. D. Cahyono, "Analisis Risiko Teknologi Informasi Menggunakan ISO 31000 pada Program HRMS," J. RESTI (Rekayasa Sist. dan Teknol. Informasi), vol. 1, no. 3, pp. 250-258, 2017, doi: 10.29207/resti.v1i3.94.

[4] H. T. I. Driantami, Suprapto, and A. R. Perdanakusuma, "Analisis Risiko Teknologi Informasi Menggunakan ISO 31000 ( Studi kasus: Sistem Penjualan PT Matahari Department Store Cabang Malang Town Square )," J. Pengemb. Teknol. Inf. dan Ilmu Komput., vol. 2, no. 11, pp. 4991-4998, 2018.

[5] F. L. Nice and R. V. Imbar, "Analisis Risiko Teknologi Informasi pada Lembaga Penerbangan dan Antariksa Nasional (LAPAN) pada Website SWIFTS Menggunakan ISO 31000," J. Inform. dan Sist. Inf., vol. 2, no. 2, pp. 1-11, 2017.

[6] D. L. Ramadhan, R. Febriansyah, and R. S. Dewi, "Analisis Manajemen Risiko Menggunakan ISO 31000 pada Smart Canteen SMA XYZ," JURIKOM (Jurnal Ris. Komputer), vol. 7, no. 1, p. 91, 2020, doi: 10.30865/jurikom.v7i1.1791.

[7] A. Novia Rilyani, Y. A. Firdaus W ST, and D. S. Dwi Jatmiko, "Analisis Risiko Teknologi Informasi Berbasis Risk Management Menggunakan ISO 31000 (Studi Kasus: iGracias Telkom University) Information Technology Risk Analysis Based On Risk Management Using Iso 31000 (Case Study : iGracias Telkom University)," e-Proceeding Eng., vol. 2, no. 2, pp. 6201-6208, 2015.

[8] Z. A. Hasibuan, "Metodologi Penelitian Pada Bidang Ilmu Komputer Dan Teknologi Informasi," Konsep, Tek. Dan Apl., no. Universitas Indonesia, p. 194, 2007.

[9] ISO 31000, "International Organization for Standardization ISO 31000: Risk management - Principles and guidelines," vol. 2009, p. 36, 2009. 
[10] G. W. Lantang, A. D. Cahyono, and N. Ngalumsine, "Analisis Risiko Teknologi Informasi Pada Aplikasi Sap Di Pt Serasi Autoraya Menggunakan Iso 31000," Sebatik 2621-069X, vol. 23 No. 1, pp. 36-43, 2019, doi: 1410-3737. 